\title{
The Differences in Egg Quality of White Leghorn and Naked Neck Chicken
}

\author{
Kostaman T, Sopiyana S \\ Indonesian Research Institute of Animal Production \\ PO Box 221, Bogor 16002, West Java, Indonesia \\ tatankostaman@gmail.com
}

\begin{abstract}
Evaluation of egg quality characteristics and influencing factors are very important to note. One of the factors that affect the quality of the egg is the breed of chicken. The research objective was to compare some parameters of egg quality between White Leghorn (WL) and Naked Neck chicken. Number of eggs collected were 49 eggs from WL and 59 eggs from Naked Neck. All variable egg quality was measured using an egg multi tester EMT-5200. For egg white grading, it was used the standards of the USDA (grade AA, A, and B). The average of egg weight was significantly $(\mathrm{P}<0.05)$ influenced by the breeds. Thickness of eggshell were significantly different $(\mathrm{P}<0.05)$ between WL and Naked Neck chicken $(0.46 \pm 0.05$ vs $0.43 \pm 0.04 \mathrm{~mm})$. Haugh units $(\mathrm{HU})$ were significantly higher in WL (67.64 \pm 9.97$)$ compared with Naked Neck chicken $(57.62 \pm 11.69)$. The percentage of the characteristics of the egg white on a WL chicken more on grade A $(47.68 \%)$ while the Naked Neck chicken on grade B $(59.18 \%)$. More yolk color WL chicken on score 4 $(52.54 \%)$ and Naked Neck chicken on score $5(48.98 \%)$. It can be concluded that, egg weight, eggshell thickness, HU, and the percentage of egg white on WL chicken showed superior than Naked Neck chicken.
\end{abstract}

Key Words: Breed, Egg Quality, Chicken

\section{INTRODUCTION}

Evaluation of egg quality characteristics and influencing factors are very important to note. One of the factors that affect the quality of the egg is the breed of chicken, which does not only affect the weight of the eggs but also against other egg characteristics, such as shell eggs (Zita et al. 2009; Hanusová et al. 2015).

White Leghorn are good layer hens with the average egg production of 280 eggs per year and sometimes reaches 300-320 eggs and begin to lay eggs at the age of 18 weeks, with minimum egg weight of $55 \mathrm{~g}$. The advantage of White Leghorn chicken are able to adapt to all environmental conditions.

Naked Neck chicken are another breed of chicken that naturally do not have feathers on the neck and considered to be one of the local chicken genetic resources in Indonesia. Naked Neck chicken allegedly came from Transylvania, Romania and spread all over the world brought by the Dutch East India Company around the 17th century (Ramsey et al. 2000). According to Islam \& Nishibori (2009), Naked Neck chicken had a good heat regulation mechanism, good adaptation to tropical environments and low nutrient requirement, and resistant to disease, as well as superior compared to the normal fluffy chickens in terms of growth, egg production, egg and meat quality. For example, in South Africa, based on Norris et al. (2007) studies showed that the growth rate of Naked Neck chicken was better $(0.169 \mathrm{~kg} /$ week $)$ compared with Venda chicken $(0.138 \mathrm{~kg} /$ week $)$ which is local chicken in South Africa. Naked Neck chicken raised at IRIAP was obtained from Bandung area, based on above argument, the research was conducted with the objective to compare egg quality from different breed of chickens. 


\section{MATERIAL AND METHODS}

\section{Samples of eggs}

White Leghorn and Naked Neck chicken used in this study were maintained in Chicken House of Indonesian Research Institute for Animal Production. Each breed of chickens was placed in groups in wire cages consisting of 6 chickens (5 females: 1 male). The age of chicken were in the period of laying. The chicken were fed commercial layer ration with the amount of 90-100 grams per head per day. Drinking water provided adlibitum.

The number of eggs collected from the chickens that are raised at IRIAP facilities were 49 eggs from White Leghorn chicken and 59 eggs from Naked Neck chicken. For quality analysis only eggs stored less than 3 days were used for samples.

\section{Measurement of eggs quality}

All variable of egg quality was measured automatically using an egg multi tester EMT-5200 (Robotmation, Co., Ltd., Tokyo, Japan).

\section{Eggs grading}

The standard egg grading used in this research was of Department of Agriculture (USDA) (2000), in which the standard of three grade were AA, A, and B. The AA egg quality has Haugh Unit (HU) score of 72 or more. The A egg quality has HU score of 6071. The B egg quality has HU 31-59.

\section{Statistical analysis}

Data were analyzed using T-test analysis using SPSS 17.0. Meanwhile, the grade and color of egg yolks were analyzed descriptively (percentage).

\section{RESULTS AND DISCUSSION}

The quality characteristics of chicken eggs have been investigated in several studies (Roberts 2010; Kocevski et al. 2011; Catli et al. 2012; Hanusová et al. 2015). The results of the quality characteristics of eggs from White Leghorn and Naked Neck chicken were presented in Table 1.

Table 1. Egg quality of two breeds of chicken

\begin{tabular}{lccc}
\hline \hline Variables & White leghorn & Naked neck & Statistic test \\
\hline Egg weight (grams) & $61.24 \pm 5.44$ & $37.66 \pm 7.37$ & $\mathrm{P}<0.05$ \\
Thickness of eggshell $(\mathrm{mm})$ & $0.46 \pm 0.05$ & $0.43 \pm 0.04$ & $\mathrm{P}<0.05$ \\
Haugh unit $(\mathrm{HU})$ & $67.64 \pm 9.97$ & $57.62 \pm 11.69$ & $\mathrm{P}<0.05$ \\
\hline
\end{tabular}

Egg weight is genetically linked to the three main components, namely eggshell, albumen, and egg yolks. Weight of egg was one of the most important variables not only for consumers, but also for eggs producers (Genchev 2012). In this study, the average of egg weight was significantly $(\mathrm{P}<0.05)$ influenced by the breed of chicken. Egg weight of White Leghorn chicken were heavier than Naked Neck chicken. Size of egg weight is 
influenced by genetic factors, age of the chicken, season, climatic conditions, nutrition, and individual chicken. The eggs weight of White Leghorn chicken is almost equal to the results of Lukanov et al. (2015) (61.58 g), whereas Naked Neck chicken is lighter than the results of the study Rajkumar et al. (2009), Isidahomen et al. (2013) and Usman et al. (2014) who got the egg weight between 52.70-57.52 g. Weight of egg gradually increased with increasing age of chickens and showed a positive correlation between egg weight and age (Rajkumar et al. 2009). Yousif \& El-Tayeb (2011) stated that the weight of the eggs had a strong and positive relationship with the other egg components (albumen, yolk and shell weight).

Eggshell is the hardest part of an eggs. Quality of eggshell is determined by the thickness and structure of the skin (Yamamoto et al. 2007). The quality thickness of egg shell is influenced by various factors including the type of chicken, chicken age, nutrition including protein source, molting status, water quality, heat stress, illness, housing, production systems, and environmental contaminants. Age affect on egg shell formation. When chicken getting older, it will produce thinner egg shell because of the reproductive function of these birds is decreasing because of age. The characteristics of the most important qualities of the egg shell is strength and thickness (Hanusová et al. 2015). There was a significant difference $(\mathrm{P}<0.05)$ between the breeds of chicken for eggshell thickness. Eggshell thickness value of White Leghorn and Naked Neck was higher than the results of the study Akinola \& Ibe (2014) and Sreenivas et al. (2013), i.e. 0.40 and $0.34 \mathrm{~mm}$ (White Leghorn chicken) and Rajkumar et al. (2009) i.e. 0.39 to $0.40 \mathrm{~mm}$ (Naked Neck Chicken).

Although the Haugh unit (HU) is the standard for determining the internal quality of eggs (such as albumen quality and freshness of the egg) (Keener et al. 2006). Internal quality of eggs usually drops with the elapsed time and depending on the egg shell and internal contents, as well as storage environments such as high temperature (Kul \& Seeker 2004). Garba et al. (2010) reported that high quality eggs have the HU range 57.95-61.86; while low-quality eggs have a value of less than 40. Haugh units of the White Leghorn higher than Naked Neck chicken. The higher the score HU demonstrate excellent albumen quality. HU of White Leghorn chickens in this study was lower than the results of Lukanov et al. (2015) study who found HU value 75.69. Similarly the value of HU Naked Neck Chicken was lower than the results Rajkumar et al. (2009) who found HU 73.9976.36 .

The percentage of egg whites of the two breeds of chicken shown in Table 2. Quality albumin is one of the most important egg quality standards, because the egg whites occupy $60 \%$ of the whole egg. Rajkumar et al. (2009) reported that large proportion of albumen likely influenced by the size of an egg. Albumen characteristics in this study according to USDA standards (2000), in White Leghorn chickens eggs majority had grade A (the albumen is clear and little bit static), while Naked Neck chicken majority is in the grade B, as characterized by the albumen look clear but already watery and it was not static.

Table 2. Percentage grade albumen from two breeds of chicken (\%)

\begin{tabular}{lcc}
\hline \hline Grade albumen & White Leghorn Chicken & Naked Neck Chicken \\
\hline AA & $38.98(23$ eggs $)$ & $8.16(4$ eggs $)$ \\
A & $47.46(28$ eggs $)$ & $32.66(16$ eggs $)$ \\
B & $13.56(8$ eggs $)$ & $59.18(29$ eggs $)$ \\
\hline
\end{tabular}

One of indicators that can be used to determine the quality of the egg is the color of the yolk. Color of egg yolk are varied in colors ranging from pale yellow to dark orange with a score ranges 1-15. The higher the color yellow. The better the quality of the eggs. 
The results showed that the color of egg yolk White Leghorn chickens ranged from 3 to 5, while Naked Neck chicken, it eggs yolk color ranging from 3 to 10 (Table 3).

Tabel 3. Percentage of yolk color score from two breeds of chicken

\begin{tabular}{ccc}
\hline \hline Yolk color score & White Leghorn & Naked Neck Chicken \\
\hline 3 & $22.04(13$ eggs $)$ & $2.04(1$ eggs $)$ \\
4 & $52.54(31$ eggs $)$ & $22.46(11$ eggs $)$ \\
5 & $25.42(15$ eggs $)$ & $48.98(24$ eggs $)$ \\
7 & - & $12.24(6$ eggs $)$ \\
8 & - & $6.12(3$ eggs $)$ \\
9 & - & $6.12(3$ eggs $)$ \\
10 & - & $2.04(1$ eggs $)$ \\
\hline
\end{tabular}

Variations in the color of egg yolk in this study were not caused by the influence of chickens breed, but was more determined by the presence or absence of xanthophyl, which are precursors of vitamin A. If the feed has a lot of yellow plant pigments known as xanthophyll, it will be stored in the egg yolk, resulted in the yolk color becomes more concentrated (World 2013). Xanthophyl are pigment of carotene from food that is fed by chicken. The pigment is transferred into the blood stream and egg yolks. As result a pigments are more deposited in the egg yolk. Approximately 7-11 circles or layers formed by each egg yolk. The total of thickness of the dark and light parts for hoarding 24 hours is approximately 1.5-2.0 mm (Yumna et al. 2014). As stated by Isidahomen et al. (2013) that the egg yolk color was more influenced by environmental rather than genetics factors. The influence of genes is not obvious to score yolk color.

\section{CONCLUSION}

According to the results of this study can be concluded that White Leghorn had higher some quality characteristics of eggs (egg weight, shell thickness, and HU) than Naked Neck chicken except the color of egg yolk. Egg yolk color of Naked Neck chicken more varied than WL chickens. The results also showed that the percentage of egg whites were influenced by the breed of chicken, but not the color of egg yolks.

\section{REFERENCES}

Akinola LAF, Ibe GC. 2014. Effect of colour, source and storage on quality of table eggs in Port Harcourt Metropolis, Rivers State, Nigeria. J Res Agric Anim Sci. 2:1-6.

Catli AU, Bozkurt M, Kucukylmaz K, Cinar M, Bintas E, Coven F, Atik H. 2012. Performance and egg quality of aged laying hens fed diets supplemented with meat and bone meal or oyster shell meal. South Afr J Anim Sci. 42:75-82.

Dunga GT. 2013. The effect of the Naked Neck (NA) and Frizzling (F) genes on the fertility, hatchability, egg quality and pterylosis of locally developed commercial layer parent lines. [thesis]. [Kumasi (Ghana)]: Kwame Nkrumah University of Science and Technology.

Garba S, Jibir M, Omojola AB. 2010. Egg quality of commercial hens fed diet fed with increasing substitution level of metabolizable energy of pearl millet for corn. Proceeding 35th Conference of Society of Animal Production, Ibadan (Nigeria): University of Ibadan. p. 308310 . 
Genchev A. 2012. Quality and composition of Japanese quail eggs (Coturnix japonica). Trakia J Sci. 10:91-101.

Hanusová E, Hrnčár C, Hanus A, Oravcová M. 2015. Effect of breed on some parameters of egg quality in laying hens. Acta Fytotechnol Zootechnol. 18:20-24.

Isidahomen CE, Njidda AA, Olatunji EA. 2013. Egg quality traits of indigenous and exotic chickens as influenced by specific genes. J Biol Agric Healthc. 3:53-57.

Islam MA, Nishibori M. 2009. Indigenous naked neck chicken: a valuable genetic resource for Bangladesh. World's Poult Sci J. 65:125-139.

Keener KM, McAvoy KC, Foegeding JB, Curtis PA, Anderson KE, Osborne JA. 2006. Effect of testing temperature on internal egg quality measurements. Poult Sci. 85:550-555.

Kocevski D, Nikolova N, Kuzelov A. 2011. The influence of strain and age on some egg quality parameters of commercial laying hens. Biotechnol Anim Husb. 27:1649-1658.

Kul S, Seeker I. 2004. Phenotypic correlations between some external and internal egg quality traits in the Japanese quail. Int J Poult Sci. 36:400-405.

Lukanov H, Genchev A, Pavlov A. 2015. Egg quality and shell colour characteristics of crosses between Araucana and Schijndelaar with highly productive White Leghorn and Rhode Island Red strains. Agric Sci Technol. 7:366-371.

Norris D, Ngambi JW, Benyi K, Makgahiela ML, Shimelis HA. 2007. Analysis of growth curves of indigenous male Venda and Naked neck chickens. South Afr J Anim Sci. 37:21-26.

Rajkumar U, Sharma RP, Rajaravindra KS, Niranjan M, Reddy BLN, Bhattacharya TK, Chatterjee RN. 2009. Effect of genotype and age on egg quality traits in Naked Neck chicken under tropical climate from India. Int J Poult Sci. 8:1151-1155.

Ramsey K, Harris L, Kotze A. 2000. Landrace breeds: South Africa's indigenous and locally adapted developed farm animals. In: Ramsey K, Harris L, Kotze A, editors. FaRrm management conditions, INFPD newsletter 2:18-20.

Roberts JR. 2010. Factors affecting egg shell and internal egg quality. J Poult Sci. 3:161-177.

Sreenivas D, Prakash MG, Mahender M, Chatterjee RN. 2013. Genetic analysis of egg quality traits in White Leghorn chicken. Vet. World 6:263-266.

United States Department of Agriculture. 2000. United states standards, grades, and weight classes for shell eggs. www.ams.usda.gov/AMSv1.0/getfile? dDocName= STELDEV3004376.

Usman M, Basheer A, Akram M, Zahoor I. 2014. A comparative study of production performance and egg quality parameters of Naked-Neck and Indigenous Aseel chicken of Pakistan. J Basic Appl Sci. 10:160-163.

Yamamoto T, Juneja LR, Hatta R, Kim M. 2007. Hen eggs basic and applied science. Alberta (Canada): University of Alberta.

Yousif IA, Eltayeb NM. 2011. Performance of Sudanese native Dwarf and Bare Neck Chicken raised under improved traditional production system. Agric Biol J North Am. 2:860-866.

Yumna MH, Zakaria A, Nurgiartiningsih VMA. 2014. Kuantitas dan kualitas telur ayam Arab (Gallus turcicus) silver dan gold. J Ilmu-Ilmu Peternakan. 23:19-24.

Zita L, Tůmová E, Štolc L. 2009. Effects of genotype, age and their interaction on egg quality in Brown-egg laying hens. Acta Vet Brno. 78:85-91. 